\title{
QUALITY IMPROVEMENT MODEL OF NURSING EDUCATION IN MUHAMMADIYAH UNIVERSITIES TOWARD COMPETITIVE ADVANTAGE
}

\author{
Abdul Aziz Alimul Hidayat, Musrifatul Uliyah, Sukadiono Sukadiono \\ Department of Nursing, Faculty of Health Science, Muhammadiyah University of \\ Surabaya Jl. Sutorejo No. 59 Surabaya \\ Email: azizhidayat@um-surabaya.ac.id
}

\begin{abstract}
Introduction: Most (90.6\%) nursing education quality in East Java is still low. That is because the quality improvement process in nursing education generally has been conducted partially (random performance improvement). A solution which might be help would be to identify a proper quality improvement model in nursing education toward competitive advantage. Method: This research used a survey to gain the data. The research sample was 16 Muhammadiyah Universities chosen using simple random sampling. The data were collected with questionnaires of 174 questions and a documentation study. Data analysis used was Partial Least Square (PLS) analysis technique. Result: The nursing education profile in Muhammadiyah Universities in Indonesia showed of 10 years establishment, accredited B and the competition level in one city/regency was averagely more than three Universities becoming the competitors. The quality improvement model analysis of nursing education towards competitive advantage in Muhammadiyah Universities was directly affected by the focus of learning and operational process through human resources management improvement; on the other hand information systems also directly affected quality improvement and quality process components: leadership, human resources, focus of learning and operational process. Improving human resources would directly influence proper strategic planning. Strategy planning was directly influenced by leadership. Thus, in improving the quality of nursing education, the leadership role of the department, proper information systems, and the human resources management improvement must be implemented. Discussion: A quality improvement model in nursing education was directly determined with learning and operational process through human resources management along with information systems, strategy planning factors, and leadership. The research findings could be developed in the quality analysis application program.
\end{abstract}

Keywords: Quality, Nursing Education, Competitive Advantage

\section{INTRODUCTION}

Education for health care professionals, especially nurses, has to be improved to prepare the professional to face the rapid challenge of the healthcare services worldwide (Frenk et al., 2010). An appropriate education must be capable preparing competent alumni who can compete whether nationally or internationally (Altuntaş and Baykal, 2017). In facing these challenges, most nursing education institutions are failing to provide a high-quality standard in responding to the demand from patients and society (Horton et al., 2010). Based on the Indonesian National Accreditation Agency for Higher Education (BAN-PT), $90.6 \%$ of nursing schools in Indonesia got a $\mathrm{C}$ grade (fair) in accreditation, some of which were nursing schools under Muhammadiyah Universities (BAN-PT, 2012).

Several things that caused the problem include that most nursing education institutions have not comprehensively conducted a quality improvement model and are still conducting it partially (Pepin et al., 2017). According to the evaluation of the quality assurance systems of the universities, from 384 universities in Indonesia, only 68 universities (17.7\%) had a good internal quality assurance system (Dikti, 2008). Moreover, the rate was lower in the nursing schools with only $7.14 \%$ with a qualified internal quality assurance system (Dikti, 2008).

Based on the background, the nursing schools need a proper quality improvement model that is heading towards competitive advantage (Kuspijadi and Sudarso, 2009; Hidayat, Supriyanto and Nursalam, 2015). Moreover, based on the prior study, the quality improvement model of nursing education for competitive advantage has not been studied.

\section{METHODS}

The method used in this study was crosssectional. The samples of the study were the Muhammadiyah universities in Indonesia - as many as sixteen universities chosen by simple random sampling. The data were collected by collecting questionnaires, which included 174 questions and performing a documentation study over three months. The data sources 
were obtained from primary and secondary sources. Primary sources were obtained from the respondents through questionnaires and direct interview, while the secondary data was taken from the accreditation results of BANPT. The data analysis technique applied in this study was Partial Least Square (PLS).

\section{RESULTS}

This study found that there were several characteristics of nursing schools selected as the samples. As many as $62.5 \%(n=10)$ of the schools were established more than ten years ago. The accreditation status of the nursing schools based on BAN-PT in Health Education showed that $87.5 \%(\mathrm{n}=14)$ of the nursing schools had a B grade (good) in accreditation, while $12.5 \%(\mathrm{n}=2)$ obtained an $\mathrm{A}$ grade (excellent). For the competitiveness, every nursing school had more than three competitor universities within the city (Table 1).

Regarding the components of the quality process in each nursing school, the results of the analysis showed that the nursing education in Muhammadiyah universities possessed a level of competitive advantage as follows: $25.0 \%$ in leadership $(\mathrm{n}=4), 75.0 \%$ in strategy planning $(\mathrm{n}=12), 50.0 \%$ in customer focus ( $\mathrm{n}$ $=8), 25.0 \%$ in human resource focus $(n=4)$, $50.0 \%$ in both learning process focus and information system $(\mathrm{n}=8)$ (Table 2).

Turning these into the components of the quality results, the results of analysis showed that nursing education in Muhammadiyah universities had an average of competitive advantage as follows: $50.0 \%(\mathrm{n}=$ $8)$ in leadership, strategy planning achievement, and customer focus; $100 \%(\mathrm{n}=$ 16 ) in the learning process and financial; while $75.0 \%(\mathrm{n}=12)$ in facilities and infrastructure. on the other hand, $87.5 \%(n=14)$ of the samples had not shown competitive advantage in the human resource component (Table 3).

The results indicated as significant if the T-statistic was higher than the outer value loading T-statistic more than 1.96 (Table 4), and the quality development model of nursing education is visualised in Figure 1.

Table 1. Profile of nursing schools under Muhammadiyah universities in 2016

\begin{tabular}{ccc}
\hline Study department profile & n & \% \\
\hline Period of existence & 0 & 0 \\
$-\quad$-5 years & 6 & 37,5 \\
$-\quad 5$ years & 10 & 62,5 \\
$-\quad \geq 10$ years & & \\
Accreditation status & 2 & 12,5 \\
$-\quad$ A (Excellent) & 14 & 87,5 \\
$-\quad$ B (Good) & 0 & 0 \\
$-\quad$ C (Fair) & 0 & 0 \\
$-\quad$ Not accredited (Poor) & & \\
The number of similar programs in a city & 0 & 0 \\
$-\quad 0-3$ & 16 & 100 \\
$-\quad>3$ &
\end{tabular}

Table 2. The components of the quality process in nursing schools under Muhammadiyah universities towards competitive advantage

\begin{tabular}{llccccc}
\hline \multirow{2}{*}{ No } & & \multicolumn{3}{c}{ Competitive advantage } \\
\cline { 3 - 6 } & & \multicolumn{3}{c}{ Yes } & \multicolumn{3}{c}{ No } \\
\hline 1 & Leadership & 4 & \% & n & \% \\
2 & Strategy planning & 12 & 75,0 & 4 & 25,0 \\
3 & Focus on customer & 8 & 50,0 & 8 & 50,0 \\
4 & Human resource focus & 4 & 25,0 & 12 & 75,0 \\
5 & Learning process focus & 8 & 50,0 & 8 & 50,0 \\
6 & Information system & 8 & 50,0 & 8 & 50,0 \\
\hline
\end{tabular}


Table 3. The components of the quality results in nursing schools under Muhammadiyah universities towards competitive advantage

\begin{tabular}{llccccc}
\hline \multirow{2}{*}{ No Result Component } & \multicolumn{3}{c}{ Competitive Advantage } \\
\cline { 3 - 6 } & & \multicolumn{3}{c}{ Yes } & \multicolumn{3}{c}{ No } \\
\hline 1 & Leadership result & 8 & 50,0 & 8 & 50,0 \\
2 & Strategy planning achievement & 8 & 50,0 & 8 & 50,0 \\
3 & The result of focusing on customer & 8 & 50,0 & 8 & 50,0 \\
4 & Management of human resource result & 2 & 12,5 & 14 & 87,5 \\
5 & The result of student process and learning & 16 & 100 & 0 & 0 \\
6 & Finance & 16 & 100 & 0 & 0 \\
7 & Facilities and infrastructure & 12 & 75,0 & 4 & 25,0 \\
\hline
\end{tabular}

Table 4. The test of the influence of variables with Partial Least Square (PLS) test

\begin{tabular}{|c|c|c|c|c|}
\hline No & The influence of variables & $\begin{array}{l}\text { Sample } \\
\text { mean }\end{array}$ & T-Statistik & Complement \\
\hline 1 & Leadership to strategy planning & 0.7423 & 15.8450 & Significant \\
\hline 2 & Strategy planning to human resource & 0.3199 & 3.3465 & Significant \\
\hline 3 & Strategy planning to the learning process & 0.2725 & 3.9500 & Significant \\
\hline 4 & Human resource to the learning process & 0.0693 & 1.9940 & significant \\
\hline 5 & $\begin{array}{l}\text { Human resource to quality improvement with a } \\
\text { competitive advantage }\end{array}$ & 0.0570 & 1.1403 & Not significant \\
\hline 6 & $\begin{array}{l}\text { Learning process to quality improvement with } \\
\text { a competitive advantage }\end{array}$ & 0.0900 & 8.9493 & Significant \\
\hline 7 & Information system to leadership & 0,6947 & 22.0510 & Significant \\
\hline 8 & Information system to human resource & 0.4193 & 4.4300 & Significant \\
\hline 9 & Information system to the learning process & 0.5477 & 7.7140 & Significant \\
\hline 10 & $\begin{array}{l}\text { Information system to quality improvement } \\
\text { with competitive advantage }\end{array}$ & 0.2186 & 13.9950 & Significant \\
\hline
\end{tabular}

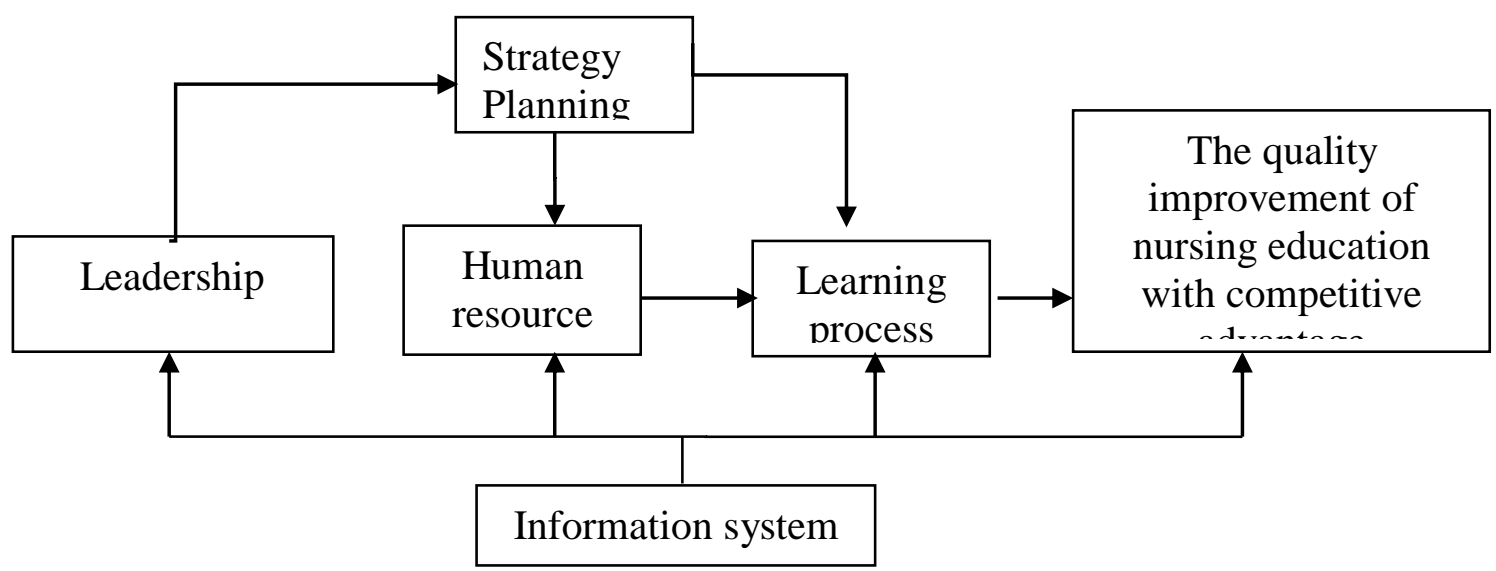

Figure 1. Quality development model of nursing education in the University of Muhammadiyah towards competitive advantage

\section{DISCUSSION}

The output of this study was the quality development model of nursing education towards competitive advantage. The model emphasised the component process and result of leading indicators, strategy planning, and information systems. It was in line with the study conducted by Teoman and Ulengin
(2016) which stated that leadership was the key to success in quality management. In addition, based on the study of Gunasekaran, Subramanian and Papadopoulos (2017), the information technology also became a key role towards competitive advantage.

In this model, the process components which directly influenced quality development 
were the component of the learning process and operational management as well as an information system. The process components were significantly influenced by human resources, while human resources were influenced by strategy planning which was influenced by leadership. In addition, all of the process components were influenced by the information system. Thus, the information system played a role in boosting quality development for every quality indicator (Semuel, Siagian and Octavia, 2017).

Based on the findings of the model developed according to the Higher Education Long Term Strategy (HELPS) 2003-2010 (DIKTI, 2004), to improve the quality of higher education and strengthen the nation's competitiveness required human resource management integrated with institutional management, and human resource management based on competence and performance (Istanto, 2012). Furthermore, the development of a model is directed to making the organisation into a customer-driven model based on a customer's needs and expectations towards competitive advantage, and the implementation of knowledge management through a knowledge sharing culture (AbdulJalal, Toulson and Tweed, 2013).

It is consistent with the model strategies developed by Kenichi Ohmae with a model of a strategic triangle, known as model 3C (corporation, customer, and competitive), which states that in achieving competitive advantage an organisation must develop a strategic business-focused corporation, customer, and competitive base (Ohmae, 1991). An organisation that wants to succeed and survive has to market what is required by the customer and remain in the competition; it needs to be superior to its competitors, and be able to create competitiveness by implementing a value creation strategy (Hitt $e t$ al., 1999).

Kenichi Ohmae states that strengthening the position of the strategy can be through the utilisation of human resources allocation, by using a relative advantage by finding the difference with competitors, using an aggressive strategic initiative to build an edge compared to other organisations, and using the strategy to innovate (Ohmae, 1991).

In winning the competition, the organisation also takes control of the management of intellectual assets; this is based on a model that can be developed in this research for the implementation of knowledge management through a knowledge sharing culture. The model is supported by Ikujiro Nonaka's SECI model that describes the life of the knowledge which undergoes a process described in a spiral shape, consisting of socialisation, externalisation, combination, and internalisation. The externalisation process is the change to explicit knowledge. The process of combination, utilising existing explicit knowledge that is implemented in another area. This process is very useful for developing skills and self-productivity. The internalisation process is changing the coming of inspiration of explicit knowledge as tacit knowledge. The socialisation process changes tacit knowledge into other tacit knowledge (Sangkala, 2007; Mulyanto, 2008).

\section{CONCLUSION}

The profile of Nursing Education at the University of Muhammadiyah in Indonesia showed on average that it was established more than 10 years ago, with a $\mathrm{B}$ accreditation status and a level of competition in the program study in a city being from an average of more than three universities that are the main contenders.

The model of quality improvement in the University of Muhammadiyah towards competitive advantage is to emphasise the components process and outcome from indicators of leadership, strategy planning, focus on customer, human resource focus, the focus of the learning process, and information systems. The model components which directly affect quality improvement are the component of the learning process and operational management and information systems. Process components are strongly influenced by human resources, and human resources are influenced by strategy planning, and strategic planning is influenced by leadership.

Quality improvement models can be used in courses that have the same indicator if you want to make universities have a competitive advantage, besides the results of research which can be developed to compile the application program to analyse the quality improvement of nursing education based electronics, to accelerate identification of the findings of the weak components of quality to be improved. 


\section{Acknowledgements}

This research is funded by the Ministry of Research, Technology, and Higher Education with Leading Universities Research Grant No. 010/SP2H/P/K7/KM/2016. Thanks to the Kopertis VII East Java for such funding and the leadership of the Chairman of Muhammadiyah Universities in Indonesia for research permits.

\section{REFFERENCES}

Abdul-Jalal, H., Toulson, P. and Tweed, D. (2013) 'Knowledge Sharing Success for Sustaining Organizational Competitive Advantage', Procedia Economics and Finance. Elsevier B.V., 7(Icebr), pp. 150-157. doi: 10.1016/S2212-5671(13)00229-3.

Altuntaş, S. and Baykal, Ü. (2017) 'An analysis of alumni performance: A study of the quality of nursing education'. doi: 10.1016/j.nedt.2016.11.022.

BAN-PT (2012) Hasil Evaluasi Status Akreditasi Program Studi bidang Kesehatan di Jawa Timur.

Dikti (2008) Hasil Evaluasi Implementasi Sistem Penjaminan Mutu Internal Perguruan Tinggi 2008, Strategy. Jakarta.

DIKTI, D. (2004) Strategi Jangka Panjang Pendidikan Tinggi (HELTS 20032010) Menuju Sinergi Kebijakan Nasional. Jakarta: Departemen Pendidikan Nasional.

Frenk, J. et al. (2010) 'Health professionals for a new century: transforming education to strengthen health systems in an interdependent world', Lancet (London, England). Jossey Bass, San Francisco, 376(9756), pp. 1923-58. doi: 10.1016/S0140-6736(10)61854-5.

Gunasekaran, A., Subramanian, N. and Papadopoulos, T. (2017) 'Information technology for competitive advantage within logistics and supply chains: A review', Transportation Research Part E: Logistics and Transportation Review, 99, pp. 14-33. doi: 10.1016/j.tre.2016.12.008.

Hidayat, A.A.A., Supriyanto, S. and Nursalam, N. (2015) 'Model of Quality Management System Using Malcolm Baldrige Criteria in Nursing Education in Surabaya', Jurnal NERS, 10(1), p. 165. doi: 10.20473/jn.V10I12015.165174.

Hitt, M.A. et al. (1999) Dynamic Strategic Resources: Development, Diffusion \& Integration. Chichester, UK: John Wiley \& Sons, Inc.

Horton, R. et al. (2010) 'A new epoch for health professionals' education', Lancet (London, England). Princeton University Press, 376(9756), pp. 1875-7. doi: 10.1016/S01406736(10)62008-9.

Istanto, Y. (2012) 'Pengaruh Strategi Keunggulan Bersaing dan Positioning terhadap Kinerja', Buletin Ekonomi, 8(2), pp. 124-135.

Kuspijadi and Sudarso (2009) Pengukuran Kinerja Fakultas Teknik Ubhara dengan Menggunakan Kriteria Malcolm Baldrige.

Mulyanto, A. (2008) Implementasi Knowledge Management untuk Meningkatkan Kinerja Perguruan Tinggi. IST AKPRIND, Yogyakarta.

Ohmae, K. (1991) The Mind Of The Strategist: The Art of Japanese Business, McGraw-Hill.

Pepin, J. et al. (2017) 'A nursing education research framework for transformative learning and interdependence of academia and practice Nurse Education Today, 52, pp. 50-52. doi: 10.1016/j.nedt.2017.02.001.

Sangkala (2007) Knowladge Managament; suatu pengantar memahami bagaimana organisasi mengelola pengetahuan sehingga menjadi organisasi yang unggul. Jakarta: PT Raja Grafindo Persada.

Semuel, H., Siagian, H. and Octavia, S. (2017) 'The Effect of Leadership and Innovation on Differentiation Strategy and Company Performance', Procedia - Social and Behavioral Sciences, 237, pp. 1152-1159. doi: 10.1016/j.sbspro.2017.02.171.

Teoman, S. and Ulengin, F. (2016) 'The impact of management leadership on quality performance throughout a supply chain: an empirical study', Total Quality Management and Business Excellence. doi: 10.1080/14783363.2016.1266244. 